\title{
Article \\ Dissolved Methane in Coastal Waters of the Northeastern Black Sea
}

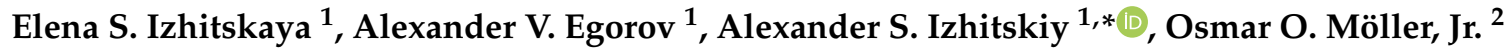 \\ and Peter O. Zavialov ${ }^{1}$ (D)
}

1 Shirshov Institute of Oceanology, Russian Academy of Sciences, 36, Nahimovskiy Prospekt, 117997 Moscow, Russia; kovaleva_es@ocean.ru (E.S.I.); avegorov@ocean.ru (A.V.E.); peter@ocean.ru (P.O.Z.)

2 Instituto de Oceanografia, Universidade Federal do Rio Grande (FURG) CP 474, Rio Grande 96201-900, RS, Brazil; dfsomj@furg.br

* Correspondence: izh@ocean.ru; Tel.: +7-903-119-77-66

check for updates

Citation: Izhitskaya, E.S.; Egorov, A.V.; Izhitskiy, A.S.; Möller, O.O., Jr.; Zavialov, P.O. Dissolved Methane in Coastal Waters of the Northeastern Black Sea. Water 2022, 14, 732. https://doi.org/10.3390/w14050732

Academic Editor:

Alessandro Bergamasco

Received: 19 January 2022

Accepted: 22 February 2022

Published: 25 February 2022

Publisher's Note: MDPI stays neutral with regard to jurisdictional claims in published maps and institutional affiliations.

Copyright: (c) 2022 by the authors. Licensee MDPI, Basel, Switzerland. This article is an open access article distributed under the terms and conditions of the Creative Commons Attribution (CC BY) license (https:// creativecommons.org/licenses/by/ $4.0 /)$.

\begin{abstract}
As the largest methane reservoir in the world, the Black Sea is characterized by significant variability in its dissolved methane distribution patterns. Aerobic waters in the coastal regions are influenced by various factors governing the biogeochemical processes in the water column; however, their impact on the distribution pattern of dissolved methane is not always well studied, especially in the shallow areas of the northeastern Black Sea, which have hitherto not been thoroughly covered by observations. Here, we consider the measurements of methane content in several regions of the northeastern Black Sea carried out from 2013-2017 with large and detailed spatial coverage in order to identify the key factors determining the dissolved methane pattern in each region of the study area. The $\mathrm{CH}_{4}$ pattern in the region of Sochi is dominated by the impact of river flow. The increased methane saturation in surface waters of the southeastern Crimean shelf (up to $40 \mathrm{nM}$ ) is caused by the influence of the Azov Sea outflow. The waters of the Feodosia Bay and to the south of it are mainly characterized by an increase in methane content towards the bottom (up to $100 \mathrm{nM}$ ), which is associated with water-sediment interactions and gas emission from the bottom.
\end{abstract}

Keywords: greenhouse gas; Black Sea; aerobic conditions; continental discharge; river plume; shelf area; methane production

\section{Introduction}

When studying dissolved methane in marine and fresh waters, the processes of its formation and accumulation are important in many respects such as understanding the mechanisms of the carbon cycling, prospecting for oil and gas, and estimating methane emissions to the atmosphere enhancing the greenhouse effect. It is known that methane is formed under strictly anaerobic conditions; however, biogenic methane content in oxic waters significantly exceeds the equilibrium values with atmospheric air. Such a contradiction is referred to as the oceanic methane paradox in the literature [1]. The mechanisms of methane formation in the aerobic environment are among the key tasks of modern oceanographic research. At the moment, there are two approahces considering the solution of this paradox: the presence of anaerobic microenvironments in sinking particulate matter, digestive tracts of zooplankton and fecal pellets [2] and the decomposition of organic matter (namely, demethylation of methylphosphonate) with the methane release [3].

As the largest methane water body on Earth, the Black Sea is characterized by a significant abundance of methane in the deep anaerobic zone-to $13 \times 10^{3} \mathrm{nM}$ [4]. At the same time, values close to equilibrium with atmospheric air are registered in the upper aerobic layer. A number of studies on dissolved methane have been devoted to the western coast of the Black Sea [5], northwestern shelf [6], area of the Crimean Peninsula [7], Anapa shelf [8], and Georgian sector [9]. Methane formation in situ and allochthonous supply of organic matter of natural and anthropogenic origin with continental runoff are among the 
reasons for increased methane saturation of the Black Sea coastal waters [10]. It is believed that gas emissions of cold seeps and mud volcanoes make a significant contribution to the concentration of methane in the Black Sea $[9,11]$.

The northeastern Black Sea and its coastal zone in particular are influenced by various factors governing the biogeochemical processes in the water column. The freshwater runoff of several dozens of small rivers significantly affects the physical and chemical conditions of the narrow shelf at the northeastern part of the Black Sea [12]. Moreover, this runoff can significantly increase during and shortly after intense precipitation events, which can occur in the considered area in all months of the year with maximal amounts in June, thereby strongly influencing water quality and causing active sediment load at large segments of the shelf [13]. On the other hand, the inflow of the Azov Sea water through the Kerch Strait to the Anapa shelf and southeastern shelf of the Crimean Peninsula [14,15] contributes to sediment, nutrient, and pollutant loading [16]. Recent studies [17,18] showed the spatiotemporal distribution of methane content in the northeastern Black Sea from the Kerch Strait to Sochi and from the coast to the border of the Russian economic zone, revealing the seasonal dependence of the intermediate aerobic maximum of methane content. Most of the data reviewed in this area covered the water column with bottom depths of more than $100 \mathrm{~m}$. Meanwhile, patterns of dissolved methane in more shallow parts of the region were studied fragmentarily. Methane concentrations in coastal waters near a number of settlements in the northeast Black Sea in August 1997 are considered in [10]. In the present study, the new results of discrete measurements of methane content in the regions of Sochi and Feodosia Bay are presented, including the data on distributions of dissolved methane on detailed surface sections from Sochi to Feodosia Bay across the whole northeastern Black Sea shelf (average depth-30 m). The results allow the description of the general pattern of dissolved methane distribution in the northeastern Black Sea shelf and the evaluation of the contribution of various factors of methane formation in the region.

\section{Materials and Methods}

\subsection{Study Area}

The northeastern Black Sea has a coastline of about $500 \mathrm{~km}$. The area includes the southeastern part of the Crimean Peninsula and the southern coast of the Taman peninsula, separated by the Kerch Strait, and further to the south, the zone from the Anapa shelf to the Sochi region. Feodosia Bay, considered in this study, belongs to the Crimean water area, while Golubaya Bay is part of the coastal zone to the south of the Anapa shelf (Figures 1 and 2).

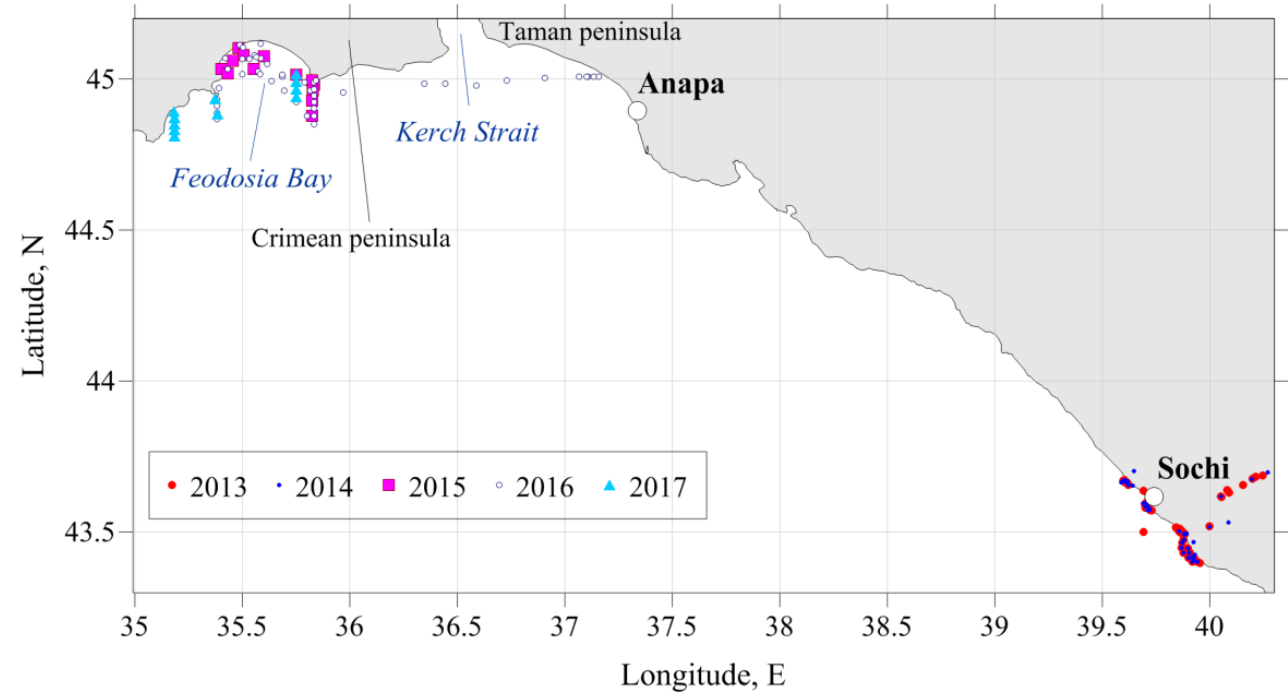

Figure 1. Location of water sampling stations in the sea and rivers of the Sochi and the Feodosia Bay regions in 2013-2017. 


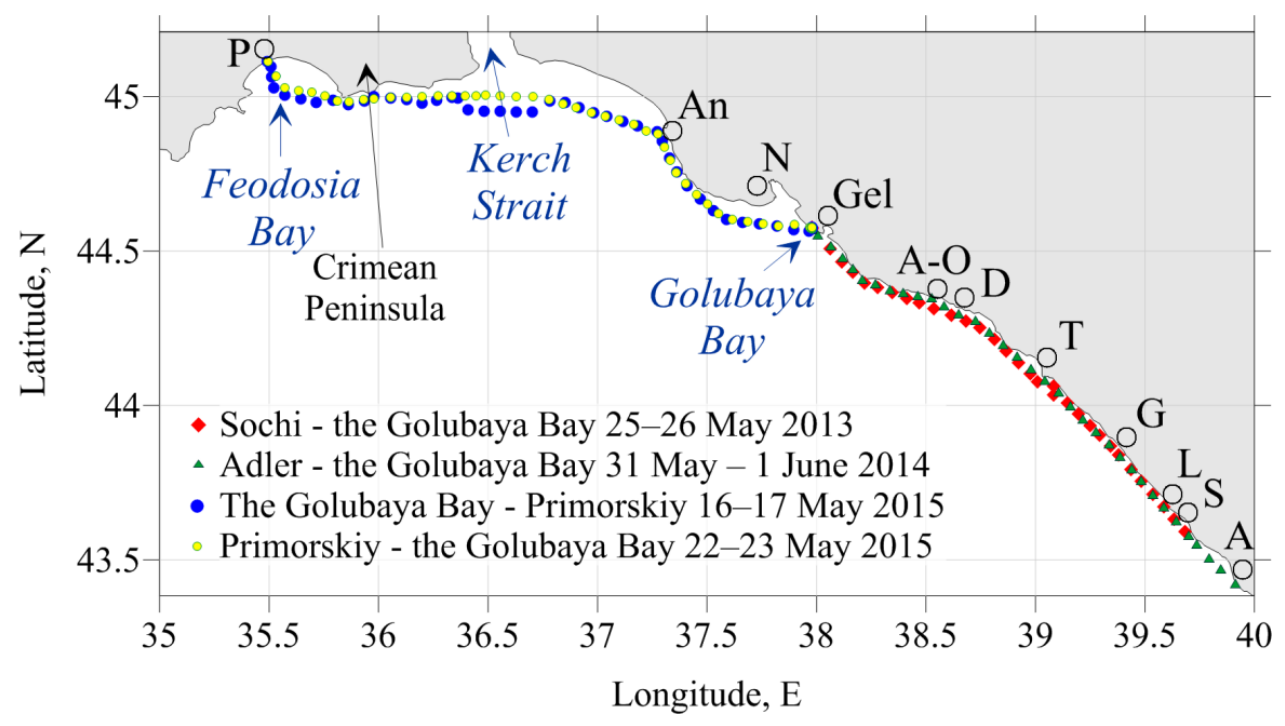

Figure 2. Location of surface water sampling stations on sections in the northeastern Black Sea in 2013-2015. P-Primorskiy, An-Anapa, N-Novorossiysk, Gel-Gelendzhik, A-O-Arkhipo-Osipovka, D-Dzubga, T-Tuapse, G—Golovinka, L-Loo, S-Sochi, A-Adler.

Data on the dissolved methane content in the surface and bottom waters were collected in the spring-summer periods (Figure 1) in the regions of the city of Sochi (2013-2014) and Feodosia Bay (2015-2017). The depths at most stations in the Sochi area reached $31 \mathrm{~m}$; however, at several stations the depths reached $200 \mathrm{~m}$. In these deep locations, samples were taken at a depth of $25 \mathrm{~m}$ instead of at the bottom. The depths reached $27 \mathrm{~m}$ in Feodosia Bay, increasing to $57 \mathrm{~m}$ in the areas to the south of the Bay. For the first time, data on the methane concentration were obtained on the following sections: two southern ones (Sochi-Golubaya Bay of Gelendzhik, 25-26 May 2013, and Adler-Golubaya Bay, 31 May-1 June 2014), two northern ones (Golubaya Bay-Primorskiy settlement of Feodosia Bay, 16-17 May 2015, and Primorskiy-Golubaya Bay, 22-23 May 2015) (Figure 2) and Anapa-Primorskiy, 23-24 May 2016 (Figure 1). The study area comprises the surface layer of a coastal zone more than $400 \mathrm{~km}$ long. In addition, methane content in the water of several rivers of the Sochi region were also measured (Figure 1).

\subsection{Water Sampling and Analysis}

Water sampling was carried out by a bucket from the surface of the sea and the rivers, and by a 51 Niskin bottle from the bottom horizons. On each station, the samples were collected into glass flasks with narrow necks (30 mL volume). The sampling procedure was as follows: a flask was filled with water with overflow of one volume to avoid blistering inside; the gas phase was formed by displacement of the water portion with a syringe. The flask was closed by a cap with a rubber insertion and stored in cool conditions and in a position where the gas phase inside had no contact with the cap to avoid gas exchange between the sample and atmospheric air. A headspace analysis procedure described in detail in $[19,20]$ was applied during laboratory processing of the obtained samples. Methane concentrations were then determined by injecting $0.5 \mathrm{~mL}$ of headspace gas into a gas chromatograph HPM-2 equipped with a flame ionization detector. The average scatter on parallel measurements was about $4 \%$.

Atmospheric equilibrium concentrations of methane in water were calculated from the equation suggested by [21] using CTD-derived in situ temperature and salinity data. 


\section{Results}

\subsection{Sochi}

The dissolved methane content in the coastal waters of the Sochi region in May 2013 exceeds the equilibrium values with atmospheric air by a factor of up to 48 times. The maximum concentrations were registered in the surface layer and were confined to the confluence of the rivers Loo, Sochi, Khosta, and Mzymta (Figure 3).
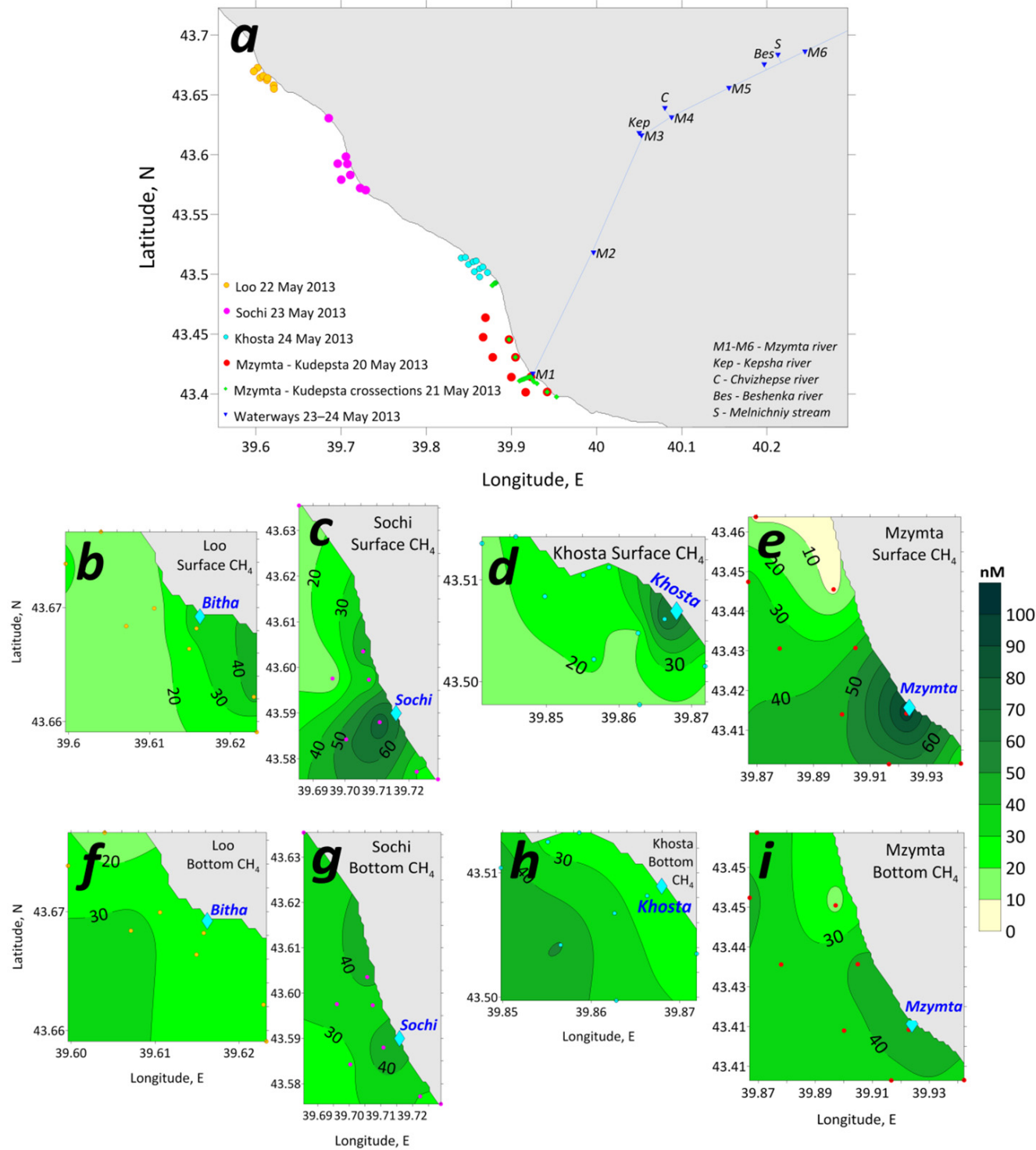

Figure 3. Location of water sampling stations in the region of Sochi, May 2013 (a). Methane content in the surface waters at polygons: Loo (b), Sochi (c), Khosta (d), Mzymta (e); methane content in the bottom waters at polygons: Loo (f), Sochi (g), Khosta (h), Mzymta (i). Blue rhombi are the river mouths.

On the marine sections in the areas where the Kudepsta and the Mzymta rivers flow (Figure S1), it is also clearly seen that methane content increases with the approach to the river mouths. However, the patterns of gas distribution in the surface and bottom layers for the two areas are directly opposite. Maximum methane concentrations near the Kudepsta river mouth are registered in the bottom waters, while the Mzymta region is characterized by an excess of surface methane values over the bottom ones. 
The methane content in the upper stream of the Mzymta river and its tributaries is relatively low (up to $10 \mathrm{nM}$ ). However, gas concentrations in the river increase to $12,000 \mathrm{nM}$ in the vicinity of the mouth (Figure 4).

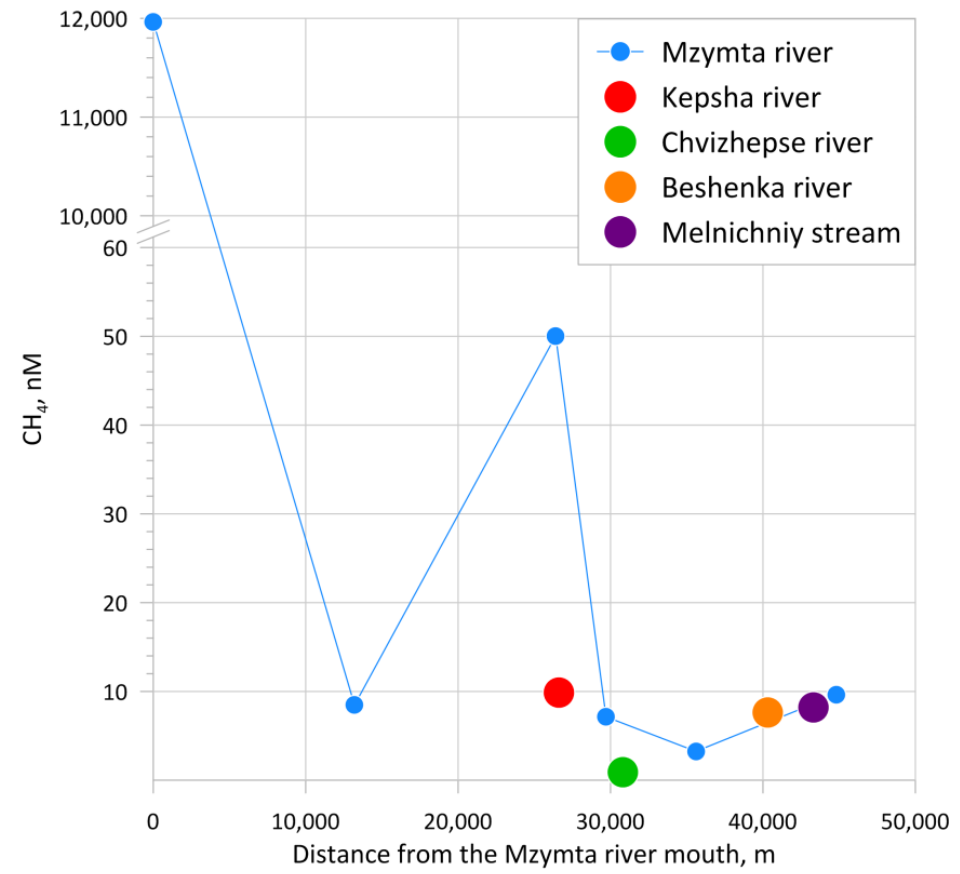

Figure 4. The dissolved methane content in freshwaters in the region of Sochi, May 2013.

On average, methane values in the Sochi region in May 2014 were similar to those of the previous year. However, in 2014, the distribution of dissolved methane was slightly different. For example, the maximum methane content near the mouth areas was recorded in the surface layer for the Bitha and Kudepsta rivers, in the bottom layer for the Sochi River, and in the bottom and intermediate layers for the Mzymta river, where the largest overall peak of the concentration was observed (Figures 5 and S2).

The methane content in the Mzymta river waters in 2014 was lower than in 2013 (Figure 6). At the same time, the tendency of methane content to increase towards the mouth area remained. In addition, the same trend is illustrated by a section with sampling stations in the Bitha River and sea water in the area of its mouth. Methane content rises downstream with a further decrease of concentrations when moved seaward. The methane concentrations in the tributaries of the Mzymta river are relatively low, as in the previous year. The maximum values of methane concentrations were recorded in the Kudepsta $(640 \mathrm{nM})$ and the Bitha $(519 \mathrm{nM})$ rivers.

\subsection{Along-Shore Sections from Sochi to Feodosia Bay}

Dissolved methane concentrations in the surface layer of the water column on the sections ranged from 1.60 to $185 \mathrm{nM}$ (Figures 2 and 7). The most notable peak of $\mathrm{CH}_{4}$ corresponded to the entrance of Golubaya Bay of Gelendzhik. According to the data of regular monitoring, the methane concentration in waters of that relatively small shallow bay is mostly determined by continental runoff (the Ashamba river); therefore, this site and the respective section near the shore will be considered separately below (Figure 8). Thus, the range of measured concentrations on sections along the coast, except the data from Golubaya Bay, was 1.60-53.3 nM with an average value of $10.7 \mathrm{nM}$.

An array of methane concentration values obtained on the alongshore transects may be organized into two groups, eastern and western, with an approximate boundary at $36.5^{\circ}$ $\mathrm{E}$ (Figures 2 and 7). The $\mathrm{CH}_{4}$ content to the east of $36.5^{\circ} \mathrm{E}$ was characterized by uneven distribution with local deviations from the average value of $7.35 \mathrm{nM}$, and, generally, did 
not exceed $10 \mathrm{nM}$. The depth at this section ranged from 12 to $51 \mathrm{~m}$; distance from the coast was $2500 \mathrm{~m}$ on average and never exceeded $5000 \mathrm{~m}$ (Figures S3 and S4). The eastern part of the section (16-17 May 2015) was different: the average $\mathrm{CH}_{4}$ concentration was $10.7 \mathrm{nM}$; the depth reached $900 \mathrm{~m}$ while the distance from the shore reached 19,600 $\mathrm{m}$. Additionally, there were several local maxima of $\mathrm{CH}_{4}$ concentrations to the east of $39^{\circ} \mathrm{E}(15.9-53.3 \mathrm{nM})$.

Regions to the west of $36.5^{\circ} \mathrm{E}$ were characterized by an increase of the dissolved methane concentration to $36.3 \mathrm{nM}$ on the first section in 2015 (May 16-17) and to $25.5 \mathrm{nM}$ on the second section (May 22-23), which was three times higher than the average concentrations of the eastern site. The average depth of the western regions was $25 \mathrm{~m}$ (in the range of 7-35 m) with varied distance from the coast that reached 14,700 $\mathrm{m}$.
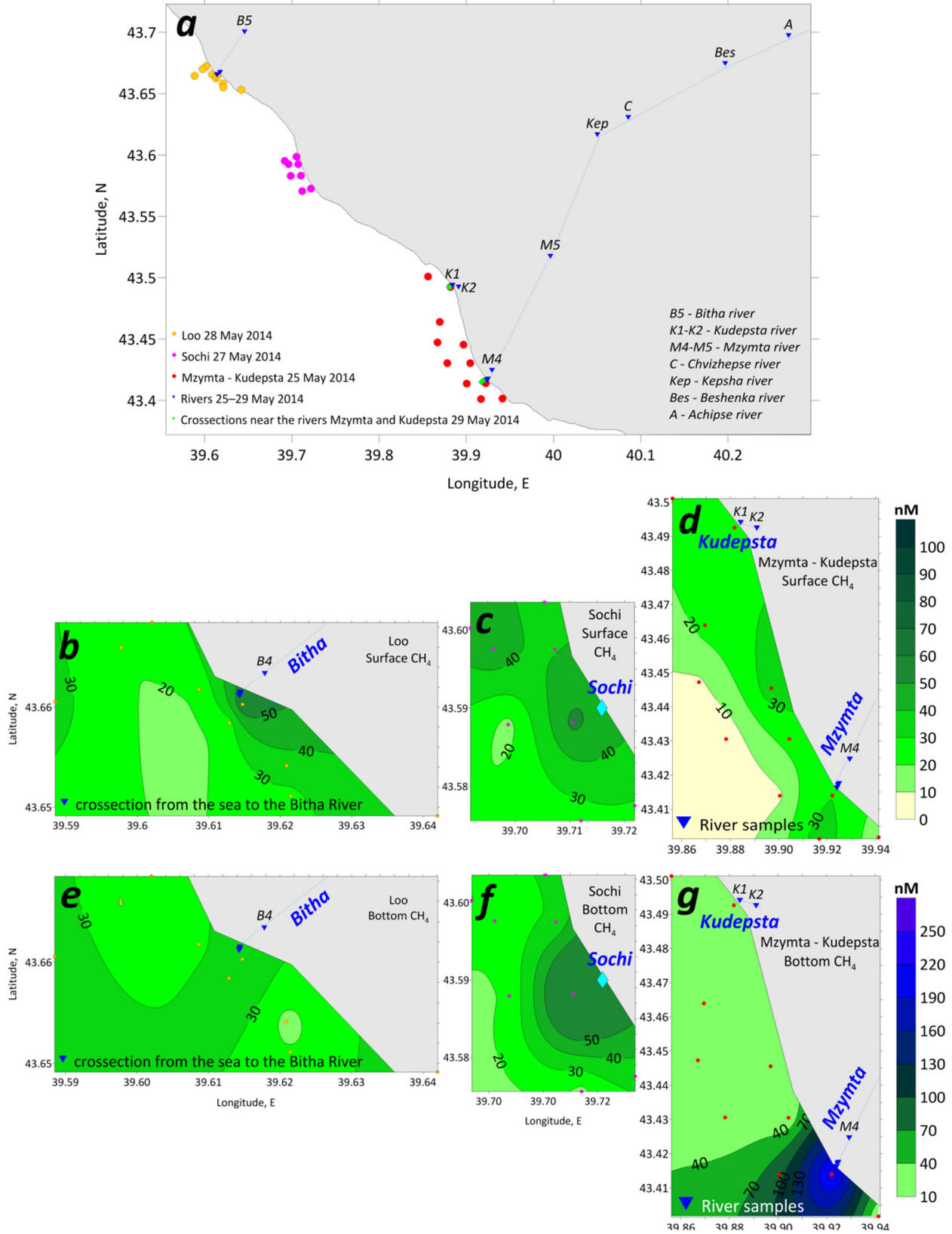

Figure 5. Location of water sampling stations in the Sochi region, May 2014 (a). Methane content in the surface waters at polygons: Loo (b), Sochi (c), Mzymta-Kudepsta (d); methane content in the bottom waters at polygons: Loo (e), Sochi (f), Mzymta-Kudepsta (g). The upper scale refers to the figure $(\mathbf{b}-\mathbf{f})$, the lower- to the figure $(\mathbf{g})$. Blue rhombi are the Sochi River mouth. 


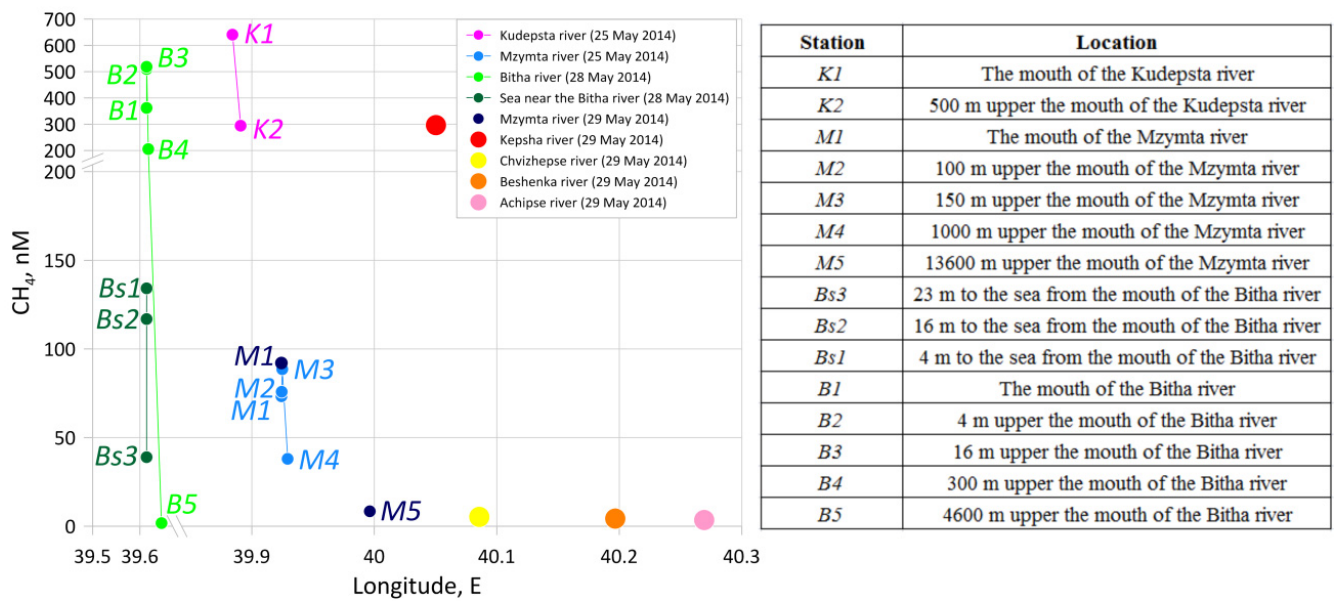

Figure 6. Dissolved methane content in the river waters of the Sochi region (as well as in the sea waters near the mouth of the Bitha River), May 2014.

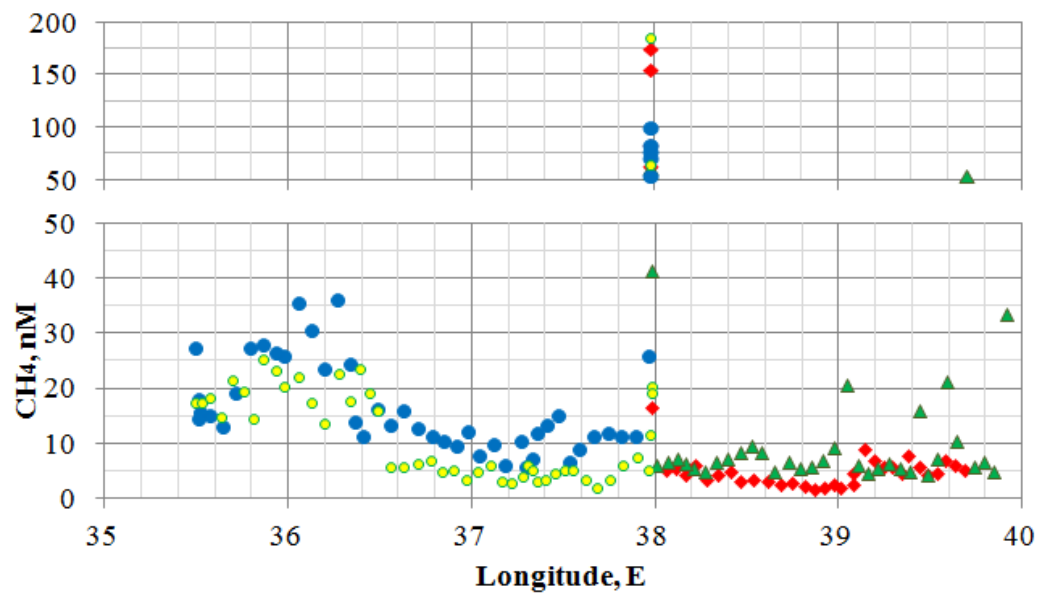
25-26 May 2013
\31 May - 1 June 2014
- 16-17 May 2015
- 22-23 May 2015

Figure 7. Dissolved methane content in the surface waters on sections in the northeastern Black Sea (2013-2015).
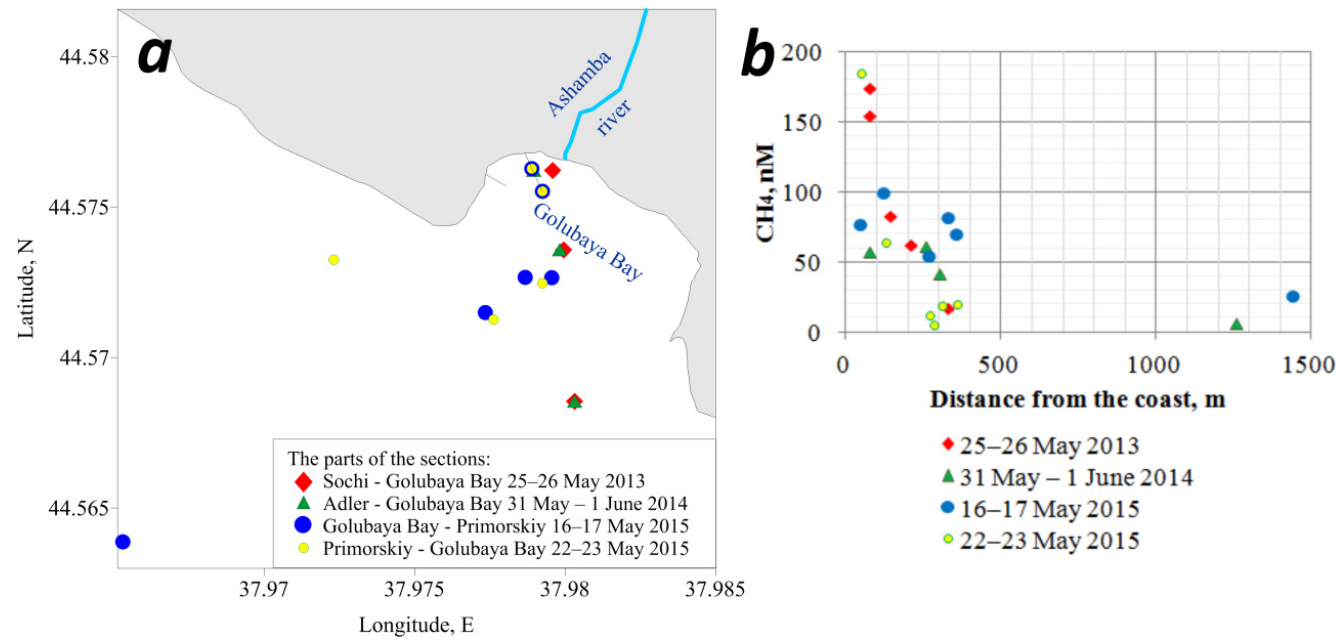

-25-26 May 2013

\ 31 May - 1 June 2014

-16-17 May 2015

-22-23 May 2015

Figure 8. Location of stations (a) and methane content (b) on the sections at the entrance to Golubaya Bay (2013-2015). 
An increase of $\mathrm{CH}_{4}$ content was observed in the direction from the open sea to the coast at the entrance to Golubaya Bay of Gelendzhik (Figure 8). The range of dissolved methane concentration values was $5.18-185 \mathrm{nM}$, while the depths increased linearly with the distance from the shore. The minimum methane content value in this region was registered at the station with a depth of $16.7 \mathrm{~m}$ at a distance of $287 \mathrm{~m}$ from the shore, while the concentration at the most seaward station was higher at $26.0 \mathrm{nM}$ (depth was $36.7 \mathrm{~m}$, distance from the coast was $1441 \mathrm{~m}$ ). Meanwhile, the maximum value of the $\mathrm{CH}_{4}$ concentration was recorded at the station with a depth of $4 \mathrm{~m}$, located $51 \mathrm{~m}$ from the shore. Based on the 2015 measurements, the $\mathrm{CH}_{4}$ saturation at the mouth of the Ashamba river flowing to Golubaya Bay was $303 \mathrm{nM}$ on 16 May and $831 \mathrm{nM}$ on 23 May.

The methane content to the south of the Kerch Strait in May 2016 reached $15 \mathrm{nM}$ and generally increased while approaching the coast to the east up to $24 \mathrm{nM}$ (Figure 9).

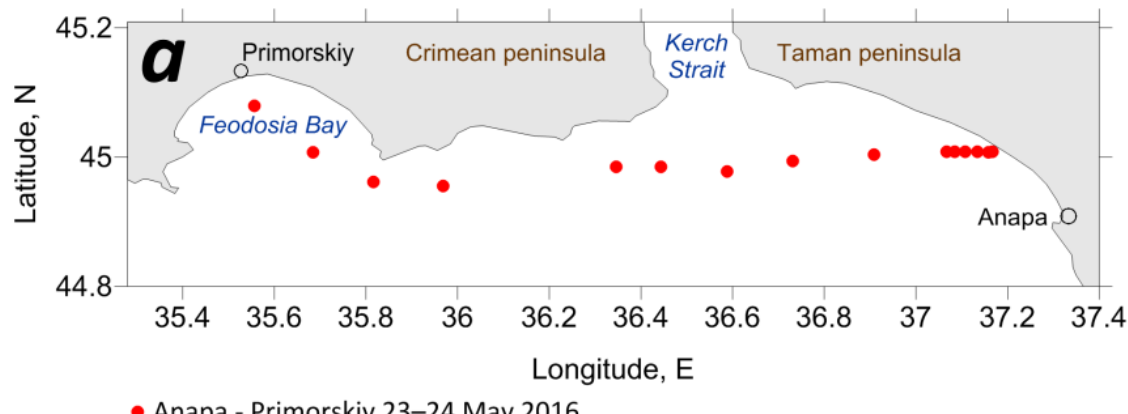

Anapa - Primorskiy 23-24 May 2016

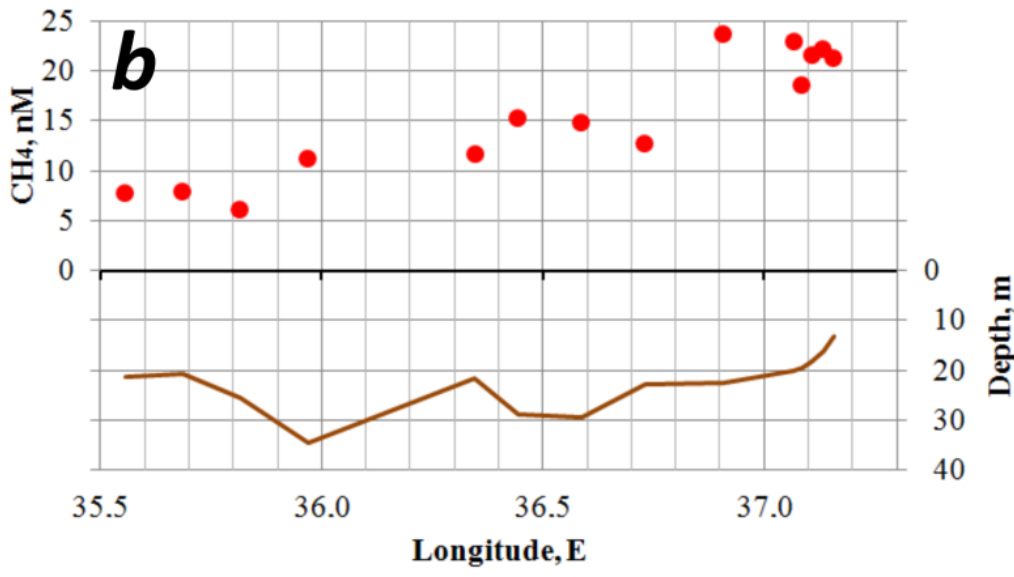

- $\mathrm{CH} 4$ surface $\quad$ Depth

Figure 9. Location of water sampling stations of the Anapa-Primorsky section in 23-24 May 2016 (a) and methane content in the surface waters and depth at the Anapa-Primorsky section (b).

\subsection{Feodosia Bay}

The excess of methane content over the equilibrium with atmospheric air reached a factor of 53 in the Feodosia Bay area in May 2015. Bottom concentrations were generally higher than surface ones (Figure 10). The maximum gas content was observed to the south of the Bay in the area of Cape Chauda (Figure 10c). 

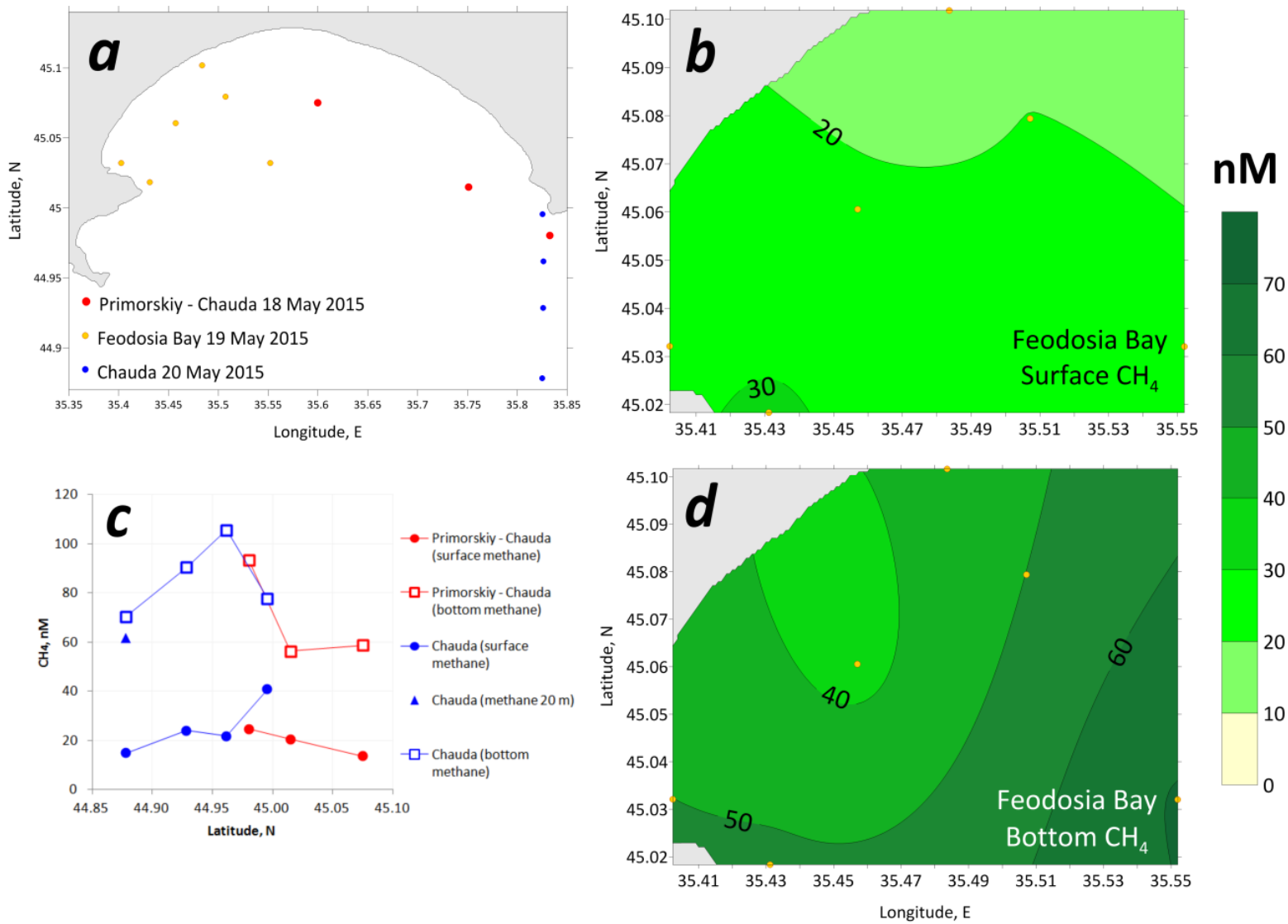

Figure 10. Location of water sampling stations in Feodosia Bay area, May 2015 (a). Methane content in the surface waters in the western part of the bay (b), on the sections (c), in the bottom waters in the western part of the bay (d).

Methane concentrations in Feodosia Bay in May 2016 reached 81 nM (Figure 11a), which is similar to the values obtained a year earlier. However, the gas distribution patterns illustrate an even more obvious difference between the surface and bottom concentrations. The maximum values of methane content were again recorded to the south of the Bay (Figure 11b).

Compared to the concentration range of the previous year, in 2017 the contrast of methane content between the surface and the bottom water in the bay was not very high. To the south of the bay, the surface methane content remained approximately at the same level as in the bay itself, while the bottom concentrations reached high values of $83 \mathrm{nM}$ (Figure 12a,d). 

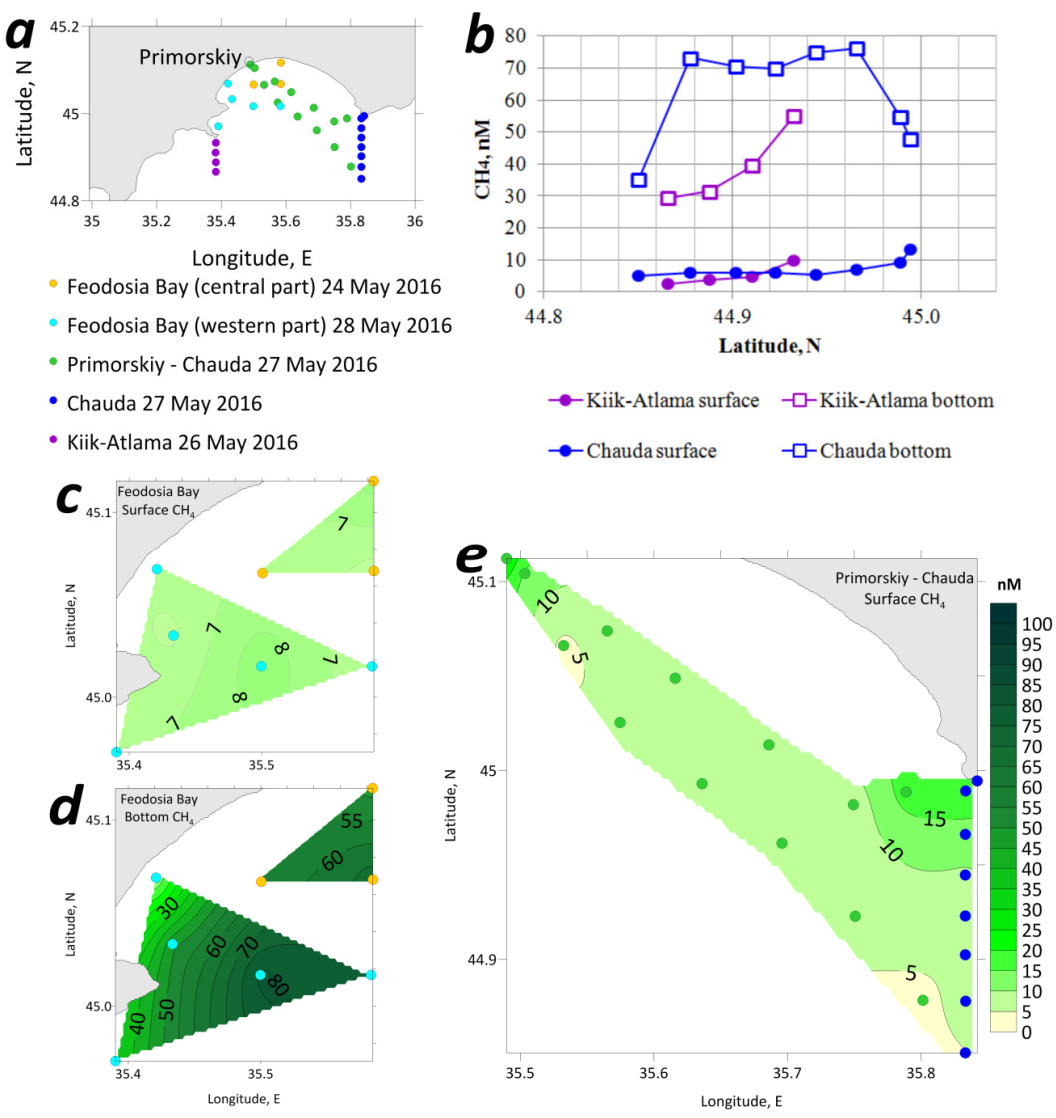

Figure 11. Location of water sampling stations in Feodosia Bay area, May 2016 (a). Methane content on sections to the south of the bay (b), in the surface (c) and bottom (d) waters in the western part of the bay and in the surface waters on the Primorsky-Chauda section (e).
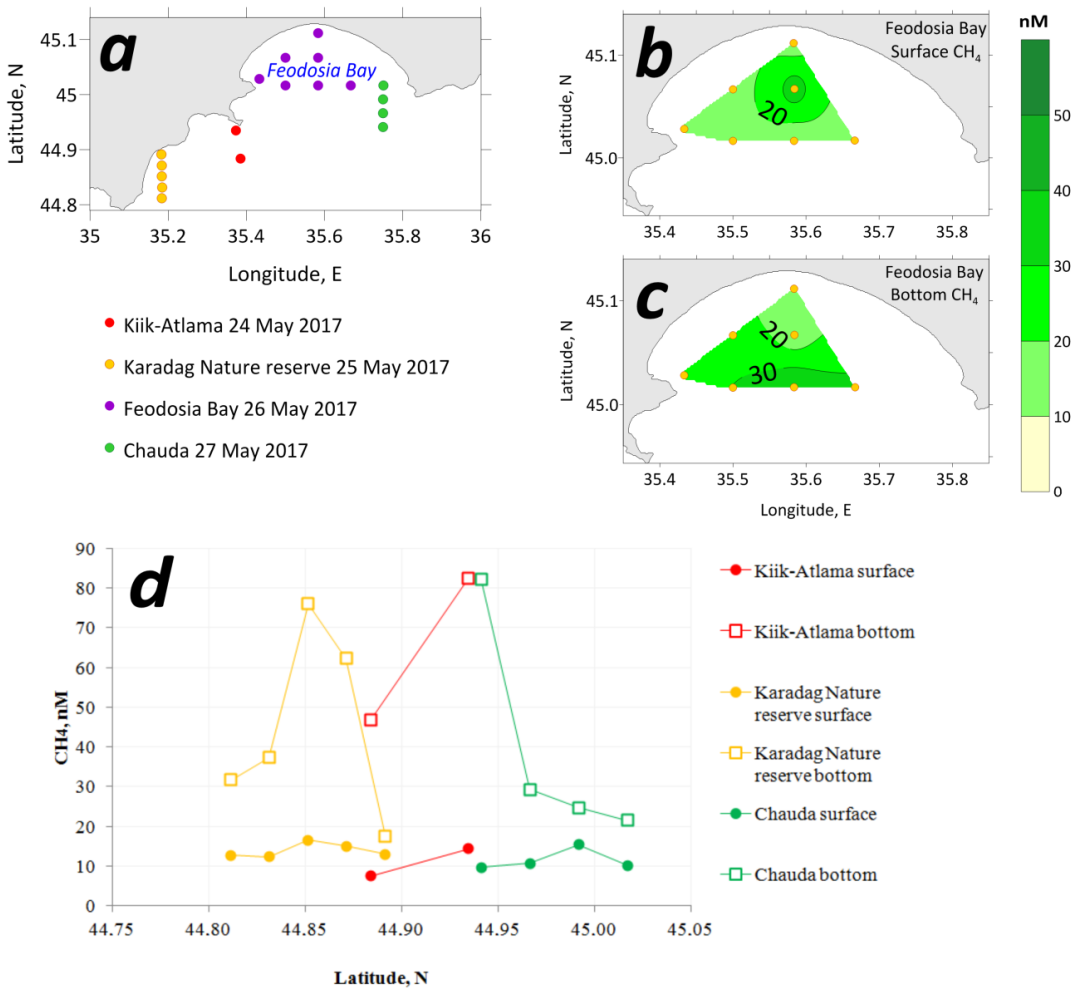

Figure 12. Location of water sampling stations in Feodosia Bay area, May 2017 (a). Methane content in the surface (b) and bottom (c) waters in the bay and on the sections to the south of the bay (d). 


\section{Discussion}

All measurements of methane concentration obtained in this study are summarized in Figure 13.

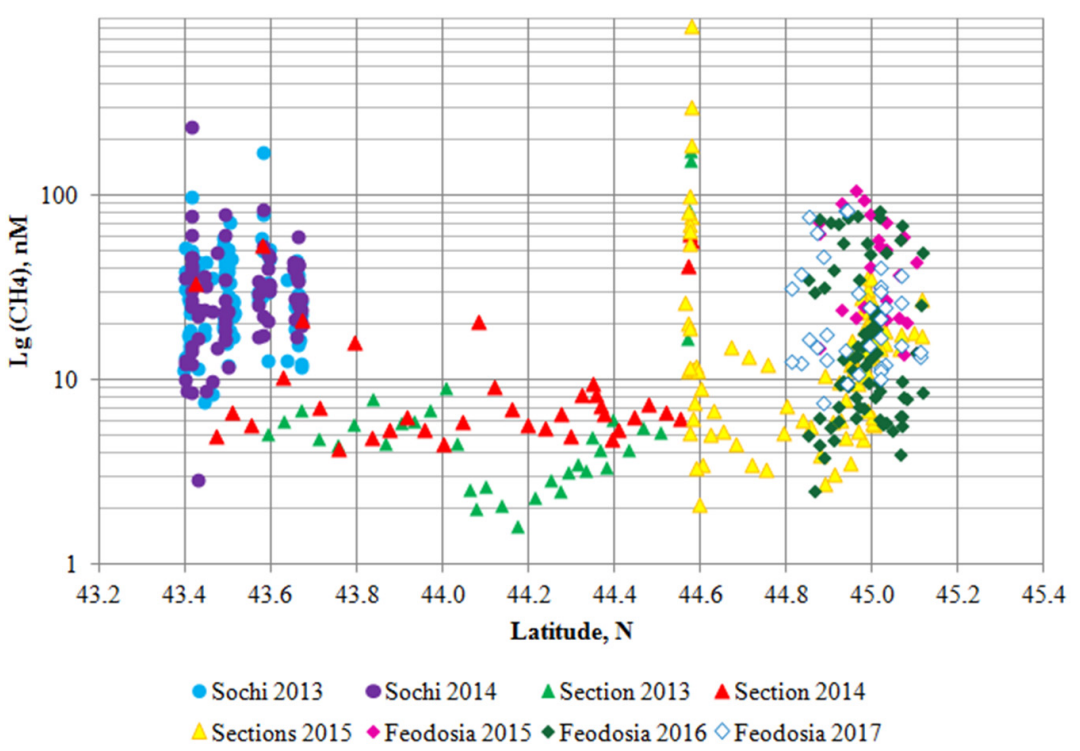

Figure 13. Methane concentrations in the regions of Sochi, Feodosia, and along-shore sections in the northeastern Black Sea (2013-2017).

\subsection{Sochi}

Since all data were collected in the same seasons in the spring-summer period, we are able to investigate the interannual variability of methane concentrations in water. According to the results of measurements obtained at several locations in the region of Sochi, the increase of methane content corresponds to the inflow of the rivers into the sea. In general, the distribution pattern of methane coincides with the distribution of salinity measured at these sites. The highest values of the correlation coefficients (Pearson) of methane content and salinity in the surface water layer in 2013 are $-0.7,-0.5$, and -0.5 for the Loo, MzymtaKudepsta, and Sochi polygons, respectively (Figure 3). In 2014, the correlation coefficient illustrates the relationship between these two parameters in the surface layer on sections near rivers Mzymta and Kudepsta (-0.6) and on the deeper horizon of the polygon Loo $(-0.6)$ (Figure 5). It is known that river waters carry a large amount of organic matter, accumulated in the coastal and estuarine areas of rivers. The organic load to the shelf could increase at times during flooding events [13]. In turn, decomposition of accumulated organic matter at the bottom may result in high values of dissolved methane concentrations being recorded in these areas [22,23]. The data show the significant saturation of waters with methane in the mouth areas of the Mzymta, Kudepsta, and Bitha rivers (Figures 4 and 6). According to the results, the methane content in river waters is 1-3 orders of magnitude higher than marine $\mathrm{CH}_{4}$ concentrations. The zone of interaction of sea and river waters is characterized by an active life of phyto- and zooplankton, which in turn leads to an increase of methane released into the water [24,25]. The mechanism of methane accumulation in coastal waters in this case may be complex. On the one hand, it may include in situ gas formation in the water, due to congestion of zooplankton. Intestinal tracts and fecal pellets of zooplankton as anaerobic microenvironments are one of the likely sources of methane [2]. Allochthonous organic matter coming within river flows from estuarine areas is an additional factor for increasing methane concentrations [26,27]. In different years, the pattern of methane distribution may vary depending on the position and configuration of river plumes and the amount of organic matter entering the sea. This appears to be the reason for the differences in the position of the noted methane maxima (either in the surface, in the water column, or near the bottom). These differences are characterized by significant 
temporal variability caused by shelf water dynamics as well. Additionally, an increased $\mathrm{CH}_{4}$ content in the water may reflect the influence of organic matter decomposition in the upper layer of bottom sediments with further output into the bottom water [28-30]. Thus, it can be clearly seen that the river flow in this region is a significant source of methane in coastal waters. Observed methane maxima in the region were of the same order as in the Arctic shelf, influenced by the large river inflows, which also provide the increase in dissolved methane concentrations [31].

\subsection{Along-Shore Sections from Sochi to Feodosia Bay}

About a third of the section's territory, namely, an area of the southeastern shelf of the Crimean Peninsula (Figure 2), is characterized by elevated methane saturation in the surface water layer, with an excess over the equilibrium values with atmospheric air by a factor of up to 93 times (Figure 7). A similar distribution of surface methane concentrations in this region in May was recorded by $[17,18]$, where coastal values from Sochi to Anapa were about $10 \mathrm{nM}$ and reached $20 \mathrm{nM}$ near the Kerch Strait. However, referring to [32], it can be noted that even with the increased summer bioproductivity of waters and the simultaneous absence of the coastal influence (the central part of the sea), the surface methane content can exceed the equilibrium with atmospheric air by a factor of up to 5 times. This suggests the presence of a significant external methanogenic factor in waters of the northeastern Black Sea. The area is affected by the Azov Sea outflow passing through the Kerch Strait. This advection, along with increased industrial and transport load, is considered to be one of the significant sources of marine pollution in the eastern Crimea [33]. The Azov Sea is influenced by continental runoff of the Don and the Kuban Rivers. In addition, as noted above, the increase of methane content is typical of seawater freshened by rivers. The $\mathrm{CH}_{4}$ concentration peaks around the Crimean Peninsula were registered at longitude $36.3^{\circ} \mathrm{E}(36.3 \mathrm{nM}$, section on 16-17 May 2015) and 35.8 $\mathrm{E}$ (25.5 nM, section on 22-23 May 2015), i.e., to the west of the Kerch Strait. With the Rim Current of the Black Sea having a cyclonic direction, and under the influence of the Coriolis force, waters of the Azov Sea normally move westward after leaving the strait. Accordingly, the Azov water flow, which is significantly freshened and enriched by organic matter in that season [24], appears to cause a methane increase in the waters of the Black Sea around the Crimea.

The wind-dependent character of the water exchange between the Sea of Azov and the Black Sea [15] may be the reason that in May 2016 we did not record a peak of methane concentrations near the southeastern coast of the Crimean Peninsula (Figure 9). This distribution graph illustrates the general trend of an increase of methane content when approaching the coast, which was also noted in measurements on sections of previous years. According to analysis of the data obtained on the alongshore sections in 2013-2015 (except area at the entrance to Golubaya Bay), there is an inverse correlation of surface methane content with depth ( -0.5 to -0.7$)$ and with distance from the coast $(-0.4$ to -0.5$)$, indicating an influence of coastal factors (continental discharge and bottom sediments). This relation is more obvious on sites of sections at the entrance to Golubaya Bay (near the coast) (Figure 8). The correlation coefficients of $\mathrm{CH}_{4}$ with a depth and distance from the coast in this area are -0.6 and -0.5 , respectively. Moreover, according to our previous measurements, the Ashamba river, flowing into Golubaya Bay, significantly impacts methane increase in sea water.

Bottom sources are among the other factors apparently causing increased methane concentrations in waters of the northeastern Black Sea shelf. Evidence of gas seepage was detected on the Taman-Anapa shelf [34]. In particular, the connection of increased $\mathrm{CH}_{4}$ content at the surface of the water column with the bottom source at a depth of $35 \mathrm{~m}$ was found in the Anapa shelf [8]. Moreover, numerous gas emissions from the seafloor at depths deeper than $85 \mathrm{~m}$ have been registered in the Kerch-Taman area since 1990. The locations of gas emission have been found on a continental slope below a depth of $200 \mathrm{~m}$ to the south of Feodosia Bay since 2007. According to [9], $\mathrm{CH}_{4}$ can reach the surface from the bottom source from depths of over $250 \mathrm{~m}$. Results of the 65th research cruise of the RV "Professor 
Vodyanitskiy" (July-August 2010) in the northeastern Black Sea showed a large number of single gas plumes and congestion of plumes at depths of 79-900 $\mathrm{m}$ in the shelf edge inflection zone, the upper and the middle parts of the continental slope [35]. Gas plumes were also registered at a depth of $30 \mathrm{~m}$ and deeper as well [36]. The horizons of water sampling within the present study did not exceed $50 \mathrm{~m}$. An increase of dissolved methane concentrations was observed on the stations to the southeast of the Crimean Peninsula, the location of which is close to that of the gas emissions studied in [36] (Figure 14). Moreover, according to atlas [37], locations of supposed mud volcanoes were registered on the Kerch-Taman shelf. Furthermore, well-shown manifestations of hydrocarbon gases coming from the seafloor to $20-40 \mathrm{~m}$ depths of the water column were observed here in 1976 [38]. Therefore, gas seepage from the seafloor could also be referenced as a potential source of elevated $\mathrm{CH}_{4}$ concentrations in the area.

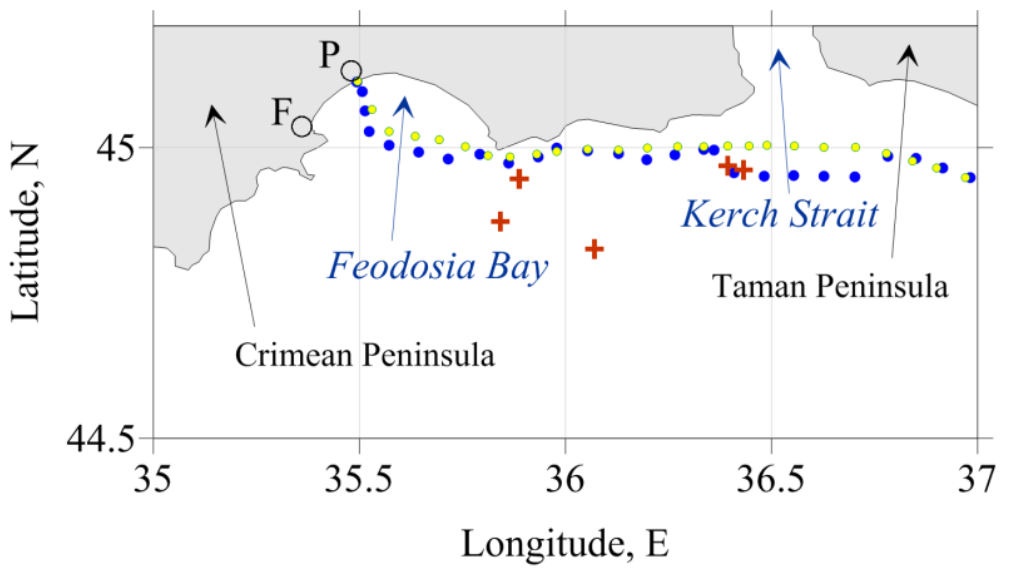

The parts of sectors:

- The Golubaya Bay - Primorskiy 16-17 May 2015

Primorskiy - the Golubaya Bay 22-23 May 2015

+ Gas showings at a depth above $100 \mathrm{~m}$, according to [Shnyukov et al., 2010b]

Figure 14. Location of sampling stations on the sections Golubaya Bay-Primorskiy (16-17 May 2015) and Primorskiy-Golubaya Bay (22-23 May 2015) in the Kerch-Taman area, as well as gas seepages at a depth above $100 \mathrm{~m}$. F-Feodosia, P-Primorskiy.

Local maxima in methane concentrations were observed in the areas along the coast (most often in the Adler-Golubaya Bay section on 31 May-1 June 2014) near the settlements of Sochi, Loo, Golovinka, and Tuapse (Figure 2). However, the values and locations of these maxima are different for each site. The wind speed during the study period was relatively low, so its influence on the distribution of methane concentrations was insignificant. On the other hand, the activity of mesoscale eddies in this area could influence the formation of a particular methane pattern in surface waters. Apparently, the elevated methane concentrations in this case are caused by the influence of the continental runoff and anthropogenic pressure. Such conclusions are in agreement with the results of [39], wherein a number of stations near the settlements of the northeastern Black Sea were considered. Those observations showed that dissolved methane content in the surface coastal waters reaches $135 \mathrm{nM}$ in August. Additionally, [10] noted that elevated methane concentrations in water at stations near Anapa and the Kerch Strait are caused by the impact of domestic and industrial wastewater on the marine ecosystem.

\subsection{Feodosia Bay}

According to the results of the measurements, the influence of the Azov water flow was not clearly visible during the period of studies in Feodosia Bay, unlike in the southeastern coast of the Crimean Peninsula, which was discussed above. In the Bay itself, we observed another peculiarity in the distribution of methane in the water column, and this pattern 
also differs from the results obtained for the Sochi region. Feodosia Bay is not influenced by river flow. However, the absolute values of the methane concentration peaks observed in the bay area are close to the values typical of river plumes in the region of Sochi. Situations in the spring of 2015, 2016, and most of 2017 illustrate that the dissolved methane rises towards the bottom in the bay waters and to the south of it (Figures 10-12). Hydrophysical data obtained on vertical profiles in the area show that the depth of the pycnocline was $15 \mathrm{~m}$ in spring 2015, $20 \mathrm{~m}$ in 2016, and $25 \mathrm{~m}$ in 2017. On the one hand, the recorded methane increase to the bottom may originate with zooplankton congestion right under the pycnocline [40]. However, the depth of the methane sampling stations significantly exceeded the depth of the pycnocline in some cases. For example, the depth reaches 26 $\mathrm{m}$ in Feodosia Bay and $56 \mathrm{~m}$ on the sections to the south. The other potential mechanism partly governing methane distribution in near-bottom water may be the gas diffusion from the upper layer of reduced sediments in the case of its presence. Then, an important point of further observation is the estimation of the vertical methane flux and the balance of methane formation and methane oxidation in the upper layer of bottom sediments [41].

\section{Conclusions}

Due to large and detailed spatial coverage of the water area, the results of this study allow the consideration of a diversity of methane sources in the region. The following common features for the study areas in the northeastern Black Sea were observed: the excess of surface methane concentrations above the equilibrium values with atmospheric air, the increase of $\mathrm{CH}_{4}$ content towards the coast, and the dependence of the spatial distribution of gas on the hydrophysical structure and dynamics of water masses. Specific peculiarities of methane distribution were identified for each of the investigated regions. The region of Sochi is dominated by the impact of river flow, which determines the pattern of methane distribution in coastal waters. The elevated methane concentrations along the coast from Sochi to Tuapse are confined to the settlements. The increased methane saturation in surface waters in the area of the southeastern Crimean shelf is likely caused by the influence of the Azov Sea outflow, especially in spring. The waters of Feodosia Bay and to the south of it are mainly characterized by an increase in the methane content towards the bottom, which may be associated with water-sediment interactions and gas emission from the bottom.

Supplementary Materials: The following are available online at https://www.mdpi.com/article/10 $.3390 / w 14050732 /$ s1, Figure S1: Location of water sampling stations on sections near the mouths of the Kudepsta and the Mzymta rivers, May 2013 (a). Blue rhombi are the river mouths. The methane content in the surface and bottom waters on the sections (b), Figure S2: Dissolved methane content on the sections near the mouths of the rivers Kudepsta (a) and Mzymta (b), May 2014. Figure S3: Depth on sections in the northeastern Black Sea (2013-2015), Figure S4: Distance from the coast on sections in the northeastern Black Sea (2013-2015).

Author Contributions: Data curation, E.S.I.; Formal analysis, E.S.I. and A.V.E.; Funding acquisition, P.O.Z.; Investigation, E.S.I. and A.S.I.; Methodology, A.V.E.; Supervision, P.O.Z.; Visualization, E.S.I.; Writing—original draft, E.S.I.; Writing—review and editing, E.S.I., A.V.E., A.S.I., O.O.M.J., and P.O.Z. All authors have read and agreed to the published version of the manuscript.

Funding: The study was supported by the Ministry of Science and Higher Education of the Russian Federation theme No. 0128-2021-0001 (field campaigns and data collection), Russian Foundation for Basic Research grant 18-35-00356 (laboratory analysis and systematization of the data set), Russian Science Foundation grant 21-17-00191 (study on dissolved methane in the Kerch strait ar-ea) and Russian Foundation for Basic Research grant 19-55-80004 (impact of river discharge on dissolved methane concentrations). O.M. Jr. acknowledges support from CNPq grants 402906/2019-5 and 302586/2019-9 (Pq).

Institutional Review Board Statement: Not applicable.

Informed Consent Statement: Not applicable. 
Data Availability Statement: The data presented in this study are available on request from the corresponding author.

Acknowledgments: Authors thank all participants of the Black Sea expeditions (2013-2017) for their help and assistance during the field work.

Conflicts of Interest: The authors declare no conflict of interest. The funders had no role in the design of the study; in the collection, analyses, or interpretation of data; in the writing of the manuscript, or in the decision to publish the results.

\section{References}

1. Kiene, R.P. Microbial Production and Consumption of Greenhouse Gases: Methane, Nitrogen Oxides, Halomethanes; Rogers, J.E., Whitman, W.B., Eds.; American Society for Microbiology: Washington, DC, USA, 1991; pp. 111-146.

2. Karl, D.M.; Tilbrook, B.D. Production and transport of methane in oceanic particulate organic matter. Nature 1994, $368,732$. [CrossRef]

3. Repeta, D.J.; Ferrón, S.; Sosa, O.A.; Johnson, C.G.; Repeta, L.D.; Acker, M.; DeLong, E.F.; Karl, D.M. Marine methane paradox explained by bacterial degradation of dissolved organic matter. Nat. Geosci. 2016, 9, 884. [CrossRef]

4. $\quad$ Lein, A.Y.; Ivanov, M.V. The largest methane reservoir on the Earth. Priroda 2005, 2, 19-26.

5. Dimitrov, P.; Dachev, V.; Nikolov, H.; Parlichev, D. Natural gas seepages in the offshore area of the Balchik Bay. Oceanology 1979, 4, 43-49.

6. Amouroux, D.; Roberts, G.; Rapsomanikis, S.; Andreae, M.O. Biogenic gas $\left(\mathrm{CH}_{4}, \mathrm{~N}_{2} \mathrm{O}\right.$, DMS) emission to the atmosphere from near-shore and shelf waters of the north-western Black Sea. Estuar. Coast. Shelf Sci. 2002, 54, 575-587. [CrossRef]

7. Egorov, V.N.; Pimenov, N.V.; Malakhova, T.V.; Kanapatsky, T.A.; Artyomov, Y.G.; Malakhova, L.V. Biogeochemical characteristics of the distribution of methane in water and bottom sediments in places of jet gas evolution in the waters of the Sevastopol bays. Mar. Environ. J. 2012, 11, 41-52. (In Russian)

8. Egorov, A.V.; Lobkovskii, L.I.; Kovachev, S.A.; Esina, E.A.; Marina, M.M.; Berlin, Y.M.; Levchenko, O.V.; Merklin, L.R. Methane anomaly in the waters of the Anapa shelf and its possible relation to oil-and-gas bearing structures. Oceanology 2008, 48, 68-76. [CrossRef]

9. Egorov, V.N.; Artemov, Y.G.; Gulin, S.B. Metanovye Sipy v Chernom More: Sredoobrazujushchaja i Ekologicheskaja rol' [The Methane Seeps in the Black Sea: Environment-Forming and Ecological Role]; NPC "EKOSI-Gidrofizika": Sevastopol, Russia, 2011; 405p. (In Russian)

10. Fedorov, Y.A.; Khoroshevskaya, V.O. Methane, mercury and hydrogen sulfide in water and bottom sediments of the northeast coast of the Black Sea. Izvestiya vysshikh uchebnykh zavedeniy. Severo-Kavkazskiy region. Yestestvennyye nauki. North Caucasus region. Nat. Sci. 2009, 5, 132-135. (In Russian)

11. Rusanov, I.I.; Lein, A.Y.; Pimenov, N.V.; Yusupov, S.K.; Ivanov, M.V. The biogeochemical cycle of methane on the northwestern shelf of the Black Sea. Microbiology 2002, 71, 479-487. [CrossRef]

12. Zavialov, P.O.; Makkaveev, P.N.; Konovalov, B.V.; Osadchiev, A.A.; Khlebopashev, P.V.; Pelevin, V.V.; Grabovskiy, A.B.; Izhitskiy, A.S.; Goncharenko, I.V.; Soloviev, D.M.; et al. Hydrophysical and hydrochemical characteristics of the sea areas adjacent to the estuaries of small rivers of the Russian coast of the Black Sea. Oceanology 2014, 54, 265-280. [CrossRef]

13. Osadchiev, A.; Korshenko, E. Small river plumes off the northeastern coast of the Black Sea under average climatic and flooding discharge conditions. Ocean. Sci. 2017, 13, 465-482. [CrossRef]

14. Izhitskiy, A.S.; Zavialov, P.O. 2017, Hydrophysical state of the Gulf of Feodosia in May. Oceanology 2015, 57, 485-491. [CrossRef]

15. Zavialov, I.; Osadchiev, A.; Sedakov, R.; Barnier, B.; Molines, J.M.; Belokopytov, V. Water exchange between the Sea of Azov and the Black Sea through the Kerch Strait. Ocean. Sci. 2020, 16, 15-30. [CrossRef]

16. Kondrat'ev, S.I. Dynamics of hydrochemical composition of waters in the Feodosia Bay as the result of water inflow from the sea of Azov during winter in 2006-2007. Ecol. Saf. Coast. Shelf Zones Complex Explor. Shelf Resour. 2009, 18, 30-38.

17. Rusanov, I.I.; Yusupov, S.K.; Zasko, D.N.; Zakharova, E.E.; Anokhina, L.L.; Pimenov, N.V. On the Nature of Methane in the Aerobic Water Column of the Black Sea//Abstracts of the All-Russian Scientific and Practical Conference "Methane in Marine Ecosystems" (META MARE 2014); "ECOSI-Hydrophysics": Sevastopol, Russia, 2014; pp. 106-109. (In Russian)

18. Rusanov, I.I.; Zasko, D.N.; Zakharova, E.E.; Anokhina, L.L.; Yusupov, S.K.; Savvichev, A.S.; Lein, A.Y.; Ivanov, M.V.; Pimenov, N.V. Peculiarities in the distribution and genesis of methane in the aerobic water column of the Black and East Arctic Seas. Geology of the seas and oceans. Materials of the XXI International Scientific Conference (School) on marine geology. M GEOS 2015, 4, 82-86. (In Russian)

19. Bolshakov, A.M.; Egorov, A.V. Methods of study of the gas composition of samples of water and bottom sediments. In Himicheskiy Analiz Morskih Osadkov [The Chemical Analysis of Water Sediments]; Nauka: Moscow, Russia, 1987; pp. 248-251. (In Russian)

20. Kampbell, D.H.; Wilson, J.T.; Vandegrift, S.A. Dissolved oxygen and methane in water by a GC headspace equilibration technique. Int. J. Environ. Anal. Chem. 1989, 36, 249-257. [CrossRef]

21. Wiesenburg, D.A.; Guinasso, N.L., Jr. Equilibrium solubilities of methane, carbon monoxide, and hydrogen in water and sea water. J. Chem. Eng. Data 1979, 24, 356-360. [CrossRef] 
22. De Angelis, M.A.; Lilley, M.D. Methane in surface waters of Oregon estuaries and rivers1. Limnol. Oceanogr. 1987, 32, 716-722. [CrossRef]

23. Fedorov, Y.A.; Tambieva, N.S.; Garkusha, D.N.; Khoroshevskaya, V.O. Metan v vodnyh Ekosistemah [Methane in Water Ecosystems]; Rostizdat: Rostov-on-Don, Russia, 2005; 329p. (In Russian)

24. Bordovskiy, O.K.; Ivanenkov, V.N. Chemistry of oceanic waters. In Okeanologija. Himija Okeana [Oceanology. Ocean Chemistry]; Nauka: Moscow, Russia, 1979; Volume 1, 518p. (In Russian)

25. Reeburgh, W.S. Oceanic methane biogeochemistry. Chem. Rev. 2007, 107, 486-513. [CrossRef]

26. Capone, D.G.; Kiene, R.P. Comparison of microbial dynamics in marine and freshwater sediments: Contrasts in anaerobic carbon catabolism. Limnol. Oceanogr. 1988, 33, 725-749. [CrossRef]

27. Lasareva, E.V.; Parfenova, A.M.; Demina, T.S.; Romanova, N.D.; Belyaev, N.A.; Romankevich, E.A. Transport of the colloid matter of riverine runoff through estuaries. Oceanology 2017, 57, 520-529. [CrossRef]

28. Martens, C.S.; Goldhaber, M.B. Early diagenesis in transitional sedimentary environments of the White Oak River Estuary, North Carolina. Limnol. Oceanogr. 1978, 23, 428-441. [CrossRef]

29. Romankevich, E.A.; Vetrov, A.A. Fluxes and masses of organic carbon in the ocean. Geochem. Int. 1997, 35, 829-836.

30. Vinogradov, M.E.; Vedernikov, V.I.; Romankevich, E.A.; Vetrov, A.A. Components of the carbon cycle in the Russian Arctic Seas: Primary production and flux of $C$ org from the photic layer. Oceanology 2000, 40, 204-215.

31. Shakhova, N.; Semiletov, I. Methane release and coastal environment in the East Siberian Arctic shelf. J. Mar. Syst. 2007, 66, 227-243. [CrossRef]

32. Reeburgh, W.S.; Ward, B.B.; Whalen, S.C.; Sandbeck, K.A.; Kilpatrickt, K.A.; Kerkhof, L.J. Black Sea methane geochemistry. Deep Sea Res. Part A Oceanogr. Res. Pap. 1991, 38, S1189-S1210. [CrossRef]

33. Lomakin, P.D.; Chepyzhenko, A.I.; Chepyzhenko, A.A. Estimation of the concentration of dissolved oil products in coastal waters of the Crimea based on optical measurements. Ekologicheskaja Bezopasnost' Pribrezhnoj i Shel'fovoj zon i Kompleksnye Issledovanija Resursov Shel'fa (Ecol. Saf. Coast. Shelf Zones Complex Investig. Shelf Resour.) 2006, 14, 245-258. (In Russian)

34. Shimkus, K.M.; Moskalenko, V.N.; Ryan, W.B.F.; Pitman, W.C., III. Gas-bearing Quaternary sediments of the Kerch area of the Black Sea shelf and their relation with the coastal lithofacies. Bjulleten' Moskovskogo Obshchestva Ispytatelej Prirody Otdelenie Geologii (Bull. Mosc. Soc. Nat. Dep. Geol.) 1998, 73, 51-55. (In Russian)

35. Shnyukov, E.F.; Emelyanov, V.A.; Kuznetsov, A.S.; Kukovskaya, T.S.; Shchiptsov, A.A. Geological and geochemical studies in the 65th cruise of the RV "Professor Vodyanitskiy" in the Black Sea (July-August 2010). Geologija i Poleznye Iskopaemye Mirovogo Okeana [Geol. Miner. Resour. World Ocean] 2010, 3, 94-98. (In Russian)

36. Shnyukov, E.F.; Pasynkov, A.A.; Lyubitskiy, A.A.; Inozemtsev, Y.I.; Rybak, E.N.; Kuznetsov, A.S. Mud volcanoes on the Kerch area of shelf and slope of the Black Sea. Geologija i Poleznye Iskopaemye Mirovogo Okeana [Geol. Miner. Resour. World Ocean] 2010, 3 , 28-36. (In Russian)

37. Shnyukov, E.F.; Sobolevskiy, Y.V.; Gnatenko, G.I.; Naumenko, P.I.; Kutniy, V.A. Grjazevye vulkany Kerchensko-Tamanskoj oblasti: Atlas [Mud volcanoes of the Kerch-Taman region: Atlas]; Naukova Dumka: Kiev, Ukraine, 1986; 152p. (In Russian)

38. Kruglyakova, R.P.; Kruglyakova, M.V.; Shevtsova, N.T. Geological and geochemical characteristics of natural hydrocarbon showings in the Black Sea. Geologija i Poleznye Iskopaemye Mirovogo Okeana [Geol. Miner. Resour. World Ocean] 2009, 1, 37-51. (In Russian)

39. Khoroshevskaya, V.O. Patterns of formation and distribution of methane in the coastal waters of the Azov-Black Sea basin. In Extended Abstract of PhD Dissertation; Southern Federal University: Rostov-on-Don, Russia, 2010. (In Russian)

40. Scranton, M.I.; Brewer, P.G. Occurrence of methane in the near-surface waters of the western subtropical North-Atlantic. Deep Sea Res. 1977, 24, 127-138. [CrossRef]

41. Reeburgh, W.S.; Heggie, D.T. Microbial methane consumption reactions and their effect on methane distributions in freshwater and marine environments 1. Limnol. Oceanogr. 1977, 22, 1-9. [CrossRef] 